\title{
Lesson Study Sebagai Upaya untuk Meningkatkan Kemampuan Guru dalam Penilaian Hasil Belajar pada Masa Pandemi Covid-19 di SDN Tanjung Mas Semarang
}

\author{
Siti Lestari \\ SDN Tanjung Mas Semarang \\ lestarisadewo@gmail.com
}

\begin{abstract}
COVID-19 is so big for education to break the chain of transmission of the COVID-19 pandemic, learning that is usually done at school is now learning at home using various applications. However, during the learning process carried out from home, the teachers of Tanjung Mas Elementary School, North Semarang Sub-district, experienced difficulties in assessing and reporting the development of students. only done by teachers based on assignments that students do and not systematically, teachers are not able to carry out assessments by conducting KKM documents, conducting tests, attitude assessments, assessments, skills assessments, daily analysis, remedial, enrichment, analysis of assessment items and question banks, from 15 There are only 6 teachers who conduct student assessments according to the rules. Therefore, teachers need lesson study activities. This study aims to answer the problems of 1) looking for lessons as an effort to increase the ability of teachers in assessing learning outcomes during the covid 19 pandemic at SDN Tanjung Mas, North Semarang District, for the 2020/2021 academic year? 2) the implementation of lesson study can improve the ability of teachers in assessing learning outcomes during the covid 19 pandemic at Tanjung Mas Elementary School, North Semarang District, for the 2020/2021 academic year?. The problem is discussed through school action research which is carried out through 2 cycles with each cycle the stages are planning, action, observation, and reflection. The results showed: 1) Lesson Study implementation as an effort to improve teacher ability in assessing learning outcomes during the covid 19 pandemic was carried out by providing opportunities for group teachers with one teacher being a model teacher and another member being an observer, any problems that occurred working in the workplace. group and discussed with other groups, the position of the researcher is to provide guidance and motivation for teacher group work to occur. 2) The implementation of lesson study can improve the ability of teachers in terms of learning outcomes during the COVID-19 pandemic at Tanjung Mas Elementary School, North Semarang District, for the 2020/2021 academic year, this can be seen from the increase in the results of teacher professionalism in classroom administration management per cycle in cycle I. teachers or $47 \%$, and in the second cycle there were 13 teachers or $87 \%$. These results indicate that these results are in line with expectations. It also occurred in teacher activities in the improvement of mini workshops where in the first cycle there were 10 teachers or $67 \%$. And up in the second cycle there were 13 teachers or $87 \%$. The increase in the implementation of mini workshops is one way for school principals to improve the ability of teachers to develop learning tools.
\end{abstract}

Keywords: Lesson Study, capacity building, Teachers, Assessment, Learning Outcomes, Pandemic Period, Covid 19.

\footnotetext{
ABSTRAK

COVID-19 begitu besar dampaknya bagi pendidikan untuk memutus rantai penularan pandemi COVID-19 pembelajaran yang biasanya dilakukan di sekolah sekarang menjadi belajar di rumah dengan menggunakan berbagai macam aplikasi. Namun selama proses pembelajaran dilakukan dari rumah, guru SDN Tanjung Mas Kecamatan Semarang Utara mengalami kesulitan untuk melakukan penilaian dan pelaporan perkembangan anak didik. Penilaian hanya dilakukan guru berdasarkan tugas yang dikerjakan siswa dan tidak sistematis, guru kuang mampu melakukan penilaian dengan melakukan Dokumen KKM, melakukan tes, penilaian sikap, penilaian pengetahuan, penilaian keterampilan, analisis penilaian harian, remedial, pengayaan, analisis butir soal
} 
penilaian dan bank soal, dari 15 Guru hanya 6 guru yang melakukan admisitrasi penilaian siswa sesuai aturan. Oleh karena itu guru membutuhkan kegiatan lesson study. Studi ini dimaksudkan untuk menjawab permasalahan 1) Bagaimanakah pelaksanaan lesson study sebagai upaya peningkatan kemampuan guru dalam penilaian hasil belajar pada masa pandemi covid 19 di SDN Tanjung Mas Kecamatan Semarang Utara Tahun Pelajaran 2020/2021?. 2) Apakah pelaksanaan lesson study dapat meningkatkan kemampuan guru dalam penilaian hasil belajar pada masa pandemi covid 19 di SDN Tanjung Mas Kecamatan Semarang Utara Tahun Pelajaran 2020/2021?. Permasalahan tersebut di bahas melalui penelitian tindakan sekolah yang dilakukan melalui 2 siklus dengan setiap siklus tahapannya adalah perencanaan, tindakan, observasi dan refleksi. Hasil penelitian menunjukkan: 1) Pelaksanaan lesson study sebagai upaya peningkatan kemampuan guru dalam penilaian hasil belajar pada masa pandemi covid 19 dilakukan dengan memberikan kesempatan kepada guru bekerja kelompok dengan salah satu guru menjadi guru model dan anggota lain menjadi pengamat, setiap permasalahan yang terjadi didiskusikan dalam kerja kelompok dan hasilnya didiskusikan dengan kelompok lain, posisi peneliti memberikan bimbingan dan motivasi terjadi kerja kelompok guru. 2) Pelaksanaan lesson study dapat meningkatkan kemampuan guru dalam penilaian hasil belajar pada masa pandemi covid 19 di SDN Tanjung Mas Kecamatan Semarang Utara Tahun Pelajaran 2020/2021, hal ini dapat dilihat dari peningkatan hasil profesionalias guru dalam pengelolaan administrasi kelas per siklus dimana pada siklus I ada 7 guru atau 47\%, dan pada siklus II sudah mencapai ada 13 guru atau 87\%. Hasil tersebut menunjukkan bahwa hasil tersebut sesuai dengan yang diharapkan. Peningkatan juga terjadi pada aktivitas guru dalam mengikuti mini worskhsop dimana pada siklus I ada 10 guru atau 67\%. Dan naik pada siklus II ada 13 guru atau 87\%. Peningkatan tersebut pelaksanaan mini workshop menjadi salah satu cara yang efektif bagi kepala sekolah dalam meningkatkan kemampuan guru dalam menyusun perangkat pembelajaran.

Kata Kunci: Lesson Study, Meningkatkan, Kemampuan, Guru, Penilaian, Hasil Belajar, Masa Pandemi, Covid 19.

\section{PENDAHULUAN}

Pembelajaran pada anak sekolah dasar agar terus berkesinambungan antara in put dan out punya membutuhkan satu bentuk penilaian untuk mengetahui perubahan perilaku siswa meliputi pengetahuan, kecakapan, pengertian, sikap ketrampilan dan sebagainya, seorang guru perlu melakukan kegiatan penilaian hasil pengalaman belajar siswa.

Namun selama proses pembelajaran dilakukan dari rumah, guru SDN Tanjung Mas Kecamatan Semarang Utara mengalami kesulitan untuk melakukan penilaian dan pelaporan perkembangan anak didik, karena penilaian merupakan proses pengukuran hasil kegiatan belajar anak yang pengukurannya dilakukan berdasarkan hasil pengamatan perilaku dan karya yang dibuat anak. Penilaian hanya dilakukan guru berdasarkan tugas yang dikerjakan siswa dan tidak sistematis, guru kuang mampu melakukan penilaian dengan melakukan Dokumen KKM, buku nilai, melakukan tes, penilaian sikap, penilaian pengetahuan, penilaian keterampilan, analisis penilaian harian, remedial, pengayaan, analisis butir soal penilaian dan bank soal, dari 15 Guru hanya 6 guru yang melakukan admisitrasi penilaian siswa dengan baik sesuai aturan.

Oleh karena itu guru dalam melakukan penialain membutuhkan kegiatan lesson study.

Lesson Study yang muncul sebagai salah satu alternatif guna mengatasi masalah praktik pembelajaran yang selama ini dipandang kurang efektif. Dalam hal ini, Lesson Study 
tampaknya dapat dijadikan sebagai salah satu alternatif guna mendorong terjadinya perubahan dalam praktik pembelajaran di Indonesia menuju ke arah yang jauh lebih efektif (Widhiartha, et.al., 2018: 7).

Ada beberapa kelebihan penggunaan lesson study, antara lain: agar memahami lebih baik bagaimana peserta didik memahami apa yang diajarkan, untuk menciptakan produk yang bias digunakan oleh pendidik lain dikelompok, untuk memperbaiki cara mengajar termasuk sistematika, penemuan secara kolaborasi, dan untuk membentuk pengetahuan pedagogik yang berdasar pada manfaatapa yang dapat guru terima sebagai pengetahuan lain dalam mengajar (Widhiartha, et.al., 2018: 36-37).

Berdasarkan latar belakang di atas peneliti tertarik untuk mengadakan penelitian tindakan sekolah tentang "Lesson Study Sebagai Upaya untuk Meningkatkan Kemampuan Guru dalam Penilaian Hasil Belajar Pada Masa Pandemi Covid 19 di SDN Tanjung Mas Kecamatan Semarang Utara Tahun Pelajaran 2020/2021”

\section{KAJIAN TEORI}

Supervisi secara etimologi adalah dari kata "super" yang berarti atas dan "visi" yang berarti melihat. Dengan demikian supervisi diartikan melihat dari atas. Berdasarkan pengertian secara etimologi, istilah-istilah supervisi yang dalam praktek, isi dan kegiatannya mengarah pada kegiatan ke-inspeksi, kepengawasan, kepemilikan (Imron, 2015: 9).

Sedangkan supervisi pendidikan menurut Glickman yang dikutip oleh Ibrahim Bafadal adalah serangkaian kegiatan membantu guru mengembangkan kemampuannya mengelola proses belajar mengajar demi pencapaian tujuan pendidikan (Bafadal, 2012: 2).

Jadi, konsep supervisi pendidikan yang dimaksud disini mempunyai 3 aspek esensial, yaitu penilaian performansi guru, perancangan pengembangan kemampuan mengajar dan pelaksanaan pengembangan kemampuan mengajar.

Lesson Study merupakan suatu pendekatan peningkatan kualitas pembelajaran yang awal mulanya berasal dari Jepang. Slamet Mulyana (2007) dalam makalahnya Ahmad Sudrajatmemberikan rumusan tentang Lesson Study sebagai salah satu model pembinaan profesi pendidik melalui pengkajian pembelajaran secara kolaboratif dan berkelanjutan berlandaskan pada prinsip-prinsip kolegalitas dan mutual learning untuk membangun komunitas belajar (Hendayana, et.al., 2017: 10).

Penilaian merupakan bagian terpenting dalam pendidikan yang bertujuan untuk mengetahui tingkat keberhasilan dalam proses belajar mengajar yang telah berlangsung. 
Dalam buku Filsafat Pendidikan Islam dijelaskan bahwa penilaian adalah proses dalam menentukan pertumbuhan, perkembangan dan kemajuan siswa dalam kegiatan belajar mengajar (Aziz, 2016: 144). Jadi, dengan adanya proses penilaian akan membantu guru dalam menentukan langkah selanjutnya.

Maka, dapat ditarik kesimpulan bahwa penilaian adalah proses yang telah direncanakan untuk mengetahui berhasil tidaknya sesuatu yang telah dilaksanakan. Menurut Arikunto (2012: 2-3), penilaian merupakan langkah kedua setelah pengukuran.

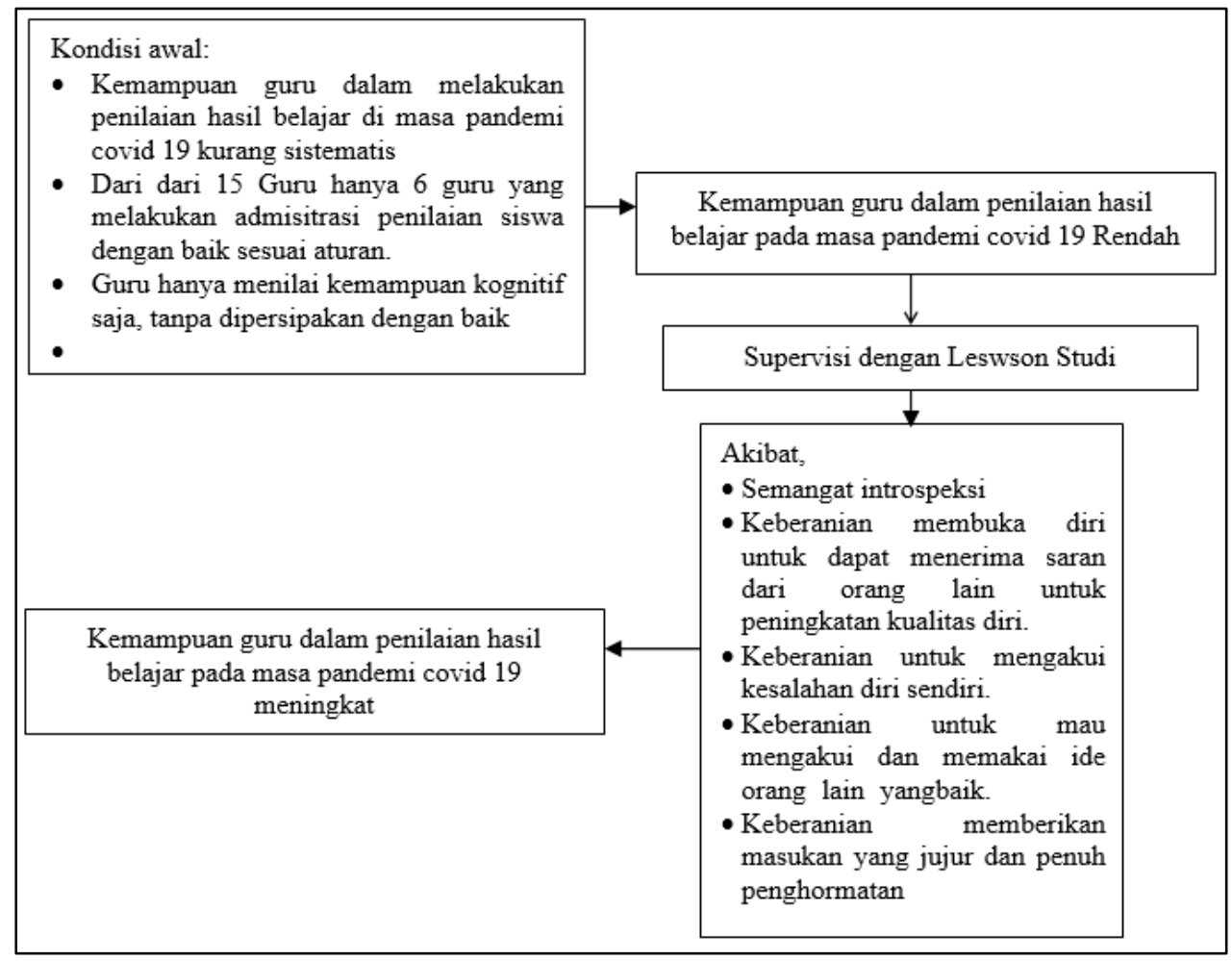

Gambar 1. Skema Kerangka Berpikir

Hipotesis tindakan dalam penelitian ini adalah pelaksanaan lesson study dapat meningkatkan kemampuan guru dalam penilaian hasil belajar pada masa pandemi covid 19 di SDN Tanjung Mas Kecamatan Semarang Utara Tahun Pelajaran 2020/2021.

\section{METODE PENELITIAN}

1. Tempat Penelitian

Tempat penelitian SDN Tanjung Mas Kecamatan Semarang Utara

\section{Waktu Penelitian}

Penelitian ini dilakukan pada tanggal 22 januari 2021 sampai 31 Maret 2021. Adapun subjek dalam penelitian ini adalah seluruh guru SDN Tanjung Mas Kecamatan Semarang Utara Tahun Pelajaran 2020/2021 sejumlah 18 guru. Variabel penelitian terdiri atas 
variabel bebas dan variabel terikat. Variabel bebas (yang mempengaruhi) dalam penelitian ini adalah pelaksanaan lesson study sedangkan variabel terikatnya (yang dipengaruhi) adalah kemampuan guru dalam penilaian hasil belajar pada masa pandemi covid 19 .

Analisis Data

1. Analisis Kualitatif

Data-data yang diperoleh dari penelitian baik melalui pengamatan, tes atau dengan menggunakan metode yang lain kemudian diolah dengan analisis deskriptif untuk menggambarkan keadaan peningkatan pencapaian indikator keberhasilan tiap siklus dan untuk menggambarkan keberhasilan.

2. Analisis Kuantitatif

Data yang berbentuk kuantitatif berupa data-data yang disajikan berdasarkan angka-angka maka analisis dilakukan dengan:

a. Penilaian Individu

Penilain individu dihitung dengan menggunakan Analisis kualitatif persentase, yaitu:

Nilai $=\frac{n}{N} x 100 \%$

Keterangan:

$\mathrm{N}=$ Jumlah Maksimal

$\mathrm{n}=$ Jumlah nilai yang diperoleh oleh guru

$\%=$ Tingkat prosentase yang dicapai

b. Ketuntasan Klasikal

Data yang diperoleh dari hasil kerja peserta dapat menentukan ketuntasan klasikal menggunakan Analisis deskriptif prosentase, dengan perhitungan:

$$
\text { Ketuntasan klasikal }=\frac{m}{M} \times 100 \%
$$

Keterangan:

$\mathrm{M}=$ Jumlah seluruh peserta

$\mathrm{m}=$ Jumlah peserta

$\%=$ Tingkat prosentase yang dicapai

Kriteria:

Baik Sekali (A) : $90<\mathrm{A} \leq 100$

Baik (B) $\quad: 70<\mathrm{B} \leq 89$ 
Cukup (C) $\quad: 60<\mathrm{C} \leq 79$

Kurang $(\mathrm{K}) \quad: \leq 60$

Sedangkan Untuk mengetahui tingkat keberhasilan penelitian tindakan sekolah ini apabila:

1. Meningkatnya kemampuan guru dalam penilaian hasil belajar pada kategori baik dan baik sekali sebanyak $85 \%$.

2. Meningkatnya aktivitas guru pada kategori baik dan baik sekali sebanyak $85 \%$

\section{HASIL PENELITIAN}

\section{Siklus I}

Pelaksanaan siklus I dilakukan pada tanggal 22 Januari. Berdasarkan hasil kerja kelompok ini peneliti menilai perangkat penilaian hasil belajar yang telah dilakukan guru. Untuk lebih jelasnya diperoleh data yang digambarkan dalam tabel dan diagram berikut:

Tabel 1. Kemampuan Guru dalam Penilaian Hasil Belajar pada Masa Pandemi Covid 19 Siklus I

\begin{tabular}{|c|c|c|c|}
\hline \multirow{2}{*}{ Kategori } & \multirow{2}{*}{ Angka } & \multicolumn{2}{|c|}{ Siklus I } \\
\cline { 3 - 4 } & & guru & $\%$ \\
\hline Baik Sekali & $90 \%-100 \%$ & 3 & $20 \%$ \\
Baik & $70 \%-89 \%$ & 4 & $27 \%$ \\
\hline Cukup & $50 \%-69 \%$ & 7 & $47 \%$ \\
Kurang & $<49 \%$ & 1 & $7 \%$ \\
\hline \multicolumn{2}{|c|}{ Jumlah } & 15 & $100 \%$ \\
\hline
\end{tabular}

Dari tabel di atas dapat diketahui kemampuan guru dalam penilaian hasil belajar pada masa pandemi covid 19 pada siklus I dimana pada kategori baik sekali sebanyak 3 guru atau $20 \%$, kategori baik sebanyak 4 guru atau 27\%, kategori cukup sebanyak 7 guru atau $47 \%$, kategori kurang sebanyak 1 guru atau7\%.

Setelah mengobservasi peserta atau guru selama proses pelaksanaan lesson study dengan menggunakan instrumen observasi yang dipegang kolabolator di dapat nilai dari aktivitas guru terutama yang terkait dengan aktivitas guru dalam memperhatikan penjelasan peneliti, aktivitas guru dalam memperhatikan penjelasan guru model, aktivitas guru dalam mengajukan pertanyaan dan meberikan jawaban, aktivitas guru dalam kerja kelompok, dan 
aktivitas guru mengomentari hasil kerja kelompok lain. Untuk lebih jelasnya diperoleh data yang digambarkan dalam tabel dan diagram berikut:

Tabel 2. Aktivitas guru dalam Pelaksanaan Lesson Study Siklus I

\begin{tabular}{|c|c|c|c|}
\hline \multirow{2}{*}{$\begin{array}{c}\text { Jumlah } \\
\text { aktivitas }\end{array}$} & \multicolumn{2}{|c|}{ Siklus I } & \multirow{2}{*}{ Kategori } \\
\cline { 2 - 3 } & Guru & $\%$ & \\
\hline $17-20$ & 4 & $27 \%$ & Sangat Aktif \\
\hline $14-16$ & 6 & $40 \%$ & Aktif \\
\hline $11-13$ & 4 & $27 \%$ & Cukup \\
\hline $8-10$ & 1 & $7 \%$ & Kurang \\
\hline $5-7$ & 0 & $0 \%$ & Tidak Aktif \\
\hline Jumlah & 15 & $100 \%$ & \\
\hline
\end{tabular}

Dari tabel di atas dapat diketahui aktivitas guru dalam pelaksanaan lesson study pada siklus I dimana pada kategori baik sekali sebanyak 4 guru atau 27\%, kategori baik sebanyak 6 guru atau 40\%, kategori cukup sebanyak 4 guru atau 27\%, kategori kurang sebanyak 1 guru atau $7 \%$.

\section{Siklus II}

Pelaksanaan siklus II dilakukan pada tanggal 26 Februari 2021. Berdasarkan hasil kerja kelompok ini peneliti menilai perangkat penilaian hasil belajar yang telah dilakukan guru. Untuk lebih jelasnya diperoleh data yang digambarkan dalam tabel dan diagram berikut:

Tabel 3. Kemampuan Guru dalam Penilaian Hasil Belajar pada Masa Pandemi Covid 19 Siklus II

\begin{tabular}{|c|c|c|c|}
\hline \multirow{2}{*}{ Kategori } & \multirow{2}{*}{ Angka } & \multicolumn{2}{|c|}{ Siklus I } \\
\cline { 3 - 4 } & & guru & $\%$ \\
\hline Baik Sekali & $90 \%-100 \%$ & 7 & $47 \%$ \\
Baik & $70 \%-89 \%$ & 6 & $40 \%$ \\
\hline Cukup & $50 \%-69 \%$ & 2 & $13 \%$ \\
Kurang & $<49 \%$ & 0 & $0 \%$ \\
\hline \multicolumn{2}{|c|}{ Jumlah } & 15 & $100 \%$ \\
\hline
\end{tabular}


Dari tabel di atas dapat diketahui kemampuan guru dalam penilaian hasil belajar pada masa pandemi covid 19 pada siklus II dimana pada kategori baik sekali sebanyak 3 guru atau $20 \%$ naik dari siklus I yaitu sebanyak 7 guru atau 27\%, kategori baik sebanyak 4 guru atau $47 \%$ naik dari siklus I yaitu sebanyak 6 guru atau 40\%, kategori cukup sebanyak 7 guru atau $47 \%$ turun dari siklus I yaitu sebanyak 2 guru atau $13 \%$.

Setelah mengobservasi peserta atau guru selama proses pelaksanaan lesson study dengan menggunakan instrumen observasi yang dipegang kolabolator, untuk lebih jelasnya diperoleh data yang digambarkan dalam tabel dan diagram berikut:

Tabel 4. Aktivitas guru dalam Pelaksanaan Lesson Study Siklus II

\begin{tabular}{|c|c|c|c|}
\hline \multirow{2}{*}{$\begin{array}{c}\text { Jumlah } \\
\text { aktivitas }\end{array}$} & \multicolumn{2}{|c|}{ Siklus I } & \multirow{2}{*}{ Kategori } \\
\cline { 2 - 3 } & Guru & $\%$ & \\
\hline $17-20$ & 6 & $40 \%$ & Sangat Aktif \\
\hline $14-16$ & 7 & $47 \%$ & Aktif \\
\hline $11-13$ & 2 & $13 \%$ & Cukup \\
\hline $8-10$ & 0 & $0 \%$ & Kurang \\
\hline $5-7$ & 0 & $0 \%$ & Tidak Aktif \\
\hline Jumlah & 15 & $100 \%$ & \\
\hline
\end{tabular}

Dari tabel di atas dapat diketahui aktivitas guru dalam pelaksanaan lesson study pada siklus II dimana pada kategori baik sekali sebanyak 4 guru atau $27 \%$ naik dari siklus I yaitu 6 guru atau 40\%, kategori baik sebanyak 6 guru atau 40\% naik dari siklus I yaitu 7 guru atau $47 \%$, kategori cukup sebanyak 4 guru atau 27\%, turun dari siklus I yaitu 2 guru atau 13\%, kategori kurang sebanyak 1 guru atau $7 \%$ turun dari siklus I yaitu 0 guru atau $0 \%$.

\section{PEMBAHASAN}

Berdasarkan hasil penelitian secara keseluruhan terjadi peningkatan kemampuan guru dalam penilaian hasil belajar pada masa pandemi covid 19 setelah dilakukan pelaksanaan lesson study di SDN Tanjung Mas Kecamatan Semarang Utara Tahun Pelajaran 2020/2021. Untuk memperjelas pembahasan tersebut dapat dilihat data sebagai berikut:

1. Kompetensi Kemampuan Guru dalam Penilaian Hasil Belajar pada Masa Pandemi Covid 19

Kemampuan guru dalam penilaian hasil belajar pada masa pandemi covid 19 di SDN Tanjung Mas Kecamatan Semarang Utara Tahun Pelajaran 2020/2021, terjadi 
peningkatan per siklusnya, untuk lebih jelasnya dapat di lihat dalam tabel dan grafik berikut:

Tabel 5. Perbandingan Kategori Kemampuan Guru dalam Penilaian Hasil Belajar pada Masa Pandemi Covid 19 Siklus I dan Siklus II

\begin{tabular}{|c|c|c|c|c|c|}
\hline \multirow{2}{*}{ Kategori } & \multirow{2}{*}{ Nilai } & \multicolumn{2}{|c|}{ Siklus I } & \multicolumn{2}{|c|}{ Siklus II } \\
\hline & & Guru & Prosentase & Guru & Prosentase \\
\hline Baik Sekali & $90-100$ & 3 & $20 \%$ & 7 & $47 \%$ \\
\hline Baik & $70-89$ & 4 & $27 \%$ & 6 & $40 \%$ \\
\hline Cukup & $50-69$ & 7 & $47 \%$ & 2 & $13 \%$ \\
\hline Kurang & $\leq 40$ & 1 & $7 \%$ & 0 & $0 \%$ \\
\hline \multicolumn{2}{|c|}{ Jumlah } & 15 & $100 \%$ & 15 & $100 \%$ \\
\hline
\end{tabular}

Berdasarkan tabel dan grafik di atas menunjukkan kemampuan guru dalam penilaian hasil belajar pada masa pandemi covid 19 pada siklus I ada 7 guru atau $47 \%$ dan pada siklus II ada 13 guru atau $87 \%$, hasil tersebut sudah mencapai indikator yang ditentukan yaitu terjadi peningkatan kemampuan guru dalam penilaian hasil belajar pada masa pandemi covid 19 di SDN Tanjung Mas Kecamatan Semarang Utara Tahun Pelajaran 2020/2021dengan pelaksanaan lesson study pada siklus I, siklus II tiap individu yang mencapai $85 \%$ dari seluruh jumlah guru.

2. Aktivitas Guru dalam Pelaksaan Lesson Study

Aktivitas guru SDN Tanjung Mas Kecamatan Semarang Utara Tahun Pelajaran 2020/2021 dalam pelaksanaan lesson study mengalami kenaikan per siklusnya, untuk lebih jelasnya dapat dilihat dalam tabel dan grafik berikut:

Tabel 6. Aktivitas Guru dalam Pelaksanaan Lesson Study Siklus I dan Siklus II

\begin{tabular}{|c|c|c|c|c|c|}
\hline \multirow{2}{*}{$\begin{array}{c}\text { Jumlah } \\
\text { Keaktifan }\end{array}$} & \multicolumn{2}{|c|}{ Siklus I } & \multicolumn{2}{c|}{ Siklus II } & \multirow{2}{*}{ Kategori } \\
\cline { 2 - 5 } & Guru & $\%$ & Guru & $\%$ & \\
\hline $17-20$ & 4 & $27 \%$ & 6 & $40 \%$ & Sangat Aktif \\
\hline $14-16$ & 6 & $40 \%$ & 7 & $47 \%$ & Aktif \\
\hline $11-13$ & 4 & $27 \%$ & 2 & $13 \%$ & Cukup \\
\hline $8-10$ & 1 & $7 \%$ & 0 & $0 \%$ & Kurang \\
\hline
\end{tabular}




\begin{tabular}{|c|c|c|c|c|c|}
$5-7$ & 0 & $0 \%$ & 0 & $0 \%$ & Tidak Aktif \\
\hline Jumlah & 15 & $100 \%$ & 15 & $100 \%$ & \\
\hline
\end{tabular}

Berdasarkan tabel dan grafik di atas menunjukkan aktivitas guru SDN Tanjung Mas Kecamatan Semarang Utara Tahun Pelajaran 2020/2021 dalam pelaksanaan lesson study pada siklus I ada 9 guru atau 67\% dan siklus II ada 13 guru atau 87\%, hasil tersebut sudah mencapai indikator yang ditentukan yaitu terjadi peningkatan aktivitas guru SDN Tanjung Mas Kecamatan Semarang Utara Tahun Pelajaran 2020/2021 dalam pelaksanaan lesson study tiap individu pada kategori baik dan sangat baik yang mencapai $85 \%$ dari seluruh jumlah guru.

Berdasarkan hasil penelitian ini maka hipotesis tindakan dalam penelitian ini yang menyatakan pelaksanaan lesson study dapat meningkatkan kemampuan guru dalam penilaian hasil belajar pada masa pandemi covid 19 di SDN Tanjung Mas Kecamatan Semarang Utara Tahun Pelajaran 2020/2021 terbukti dan diterima.

\section{SIMPULAN}

Dari hasil penelitian dan pembahasan dapat diambil kesimpulan sebagai berikut :

1. Pelaksanaan lesson study sebagai upaya peningkatan kemampuan guru dalam penilaian hasil belajar pada masa pandemi covid 19 di SDN Tanjung Mas Kecamatan Semarang Utara Tahun Pelajaran 2020/2021.

2. Pelaksanaan lesson study dapat meningkatkan kemampuan guru dalam penilaian hasil belajar pada masa pandemi covid 19 di SDN Tanjung Mas Kecamatan Semarang Utara Tahun Pelajaran 2020/2021.

\section{SARAN}

Berdasarkan penelitian dan kesimpulan yang telah peneliti lakukan, maka hal-hal yang dapat disarankan adalah sebagai berikut:

1. Kepala sekolah dan guru harus selalu adanya keinginan yang kuat untuk selalu meningkatkan kualitas pembelajarannya khusuwsnya dalam penilaian hasil belajar ssiswa.

2. Kepala sekolah sebagai penanggung jawab semua kegiatan yang ada di madrasah terlebih dulu harus memiliki komitmen yang kuat untuk selalu membina guru-guru.

3. Memasukkan kegiatan Lesson Study sebagai program sekolah dalam peningkatan kompetensi guru. 
4. Menyusun kepanitiaan atau kerja kelompok Lesson Study dalam setiap pembelajaran.

5. Melaksanakan evaluasi kegiatan Lesson Study secara berkala.

\section{DAFTAR PUSTAKA}

Abdurrahman, Mulyana, 2011, Pendidikan Bagi Anak Berkesulitan Belajar, Jakarta: Rineka Cipta

Abidin, Y., 2012, Model Penilaian Otentik Dalam Pembelajaran Membaca Pemahaman Beroreintasi Pendidikan Karakter, Jurnal Pendidikan Karakter, Tahun II, Nomor 2, Juni

Arikunto, Suharsimi, 2012, Dasar- Dasar Evaluasi Pendidikan, Jakarta: Bumi Aksara

----------, 2013, Organisasi Administrasi Pendidikan Teknologi dan Kejuruan, Jakarta: PT. Raja Grafindo Persada

, 2014, Dasar-Dasar Supervisi, Jakarta: Rineka Cipta

, 2016, Prosedur Penelitian Suatu Pendekatan Praktek, Jakarta: Rineka Cipta

, dkk, 2018, Penelitian Tindakan Sekolah, Jakarta: PT Bumi Aksara

Aziz, Abd., 2016, Filsafat Pendidikan Islam: Sebuah Gagasan Membangun Pendidikan Islam, Surabaya: ElKaf

Azwar, Saifudin, 2016, Tes Prestasi Fungsi dan Pengembangan Pengukuran Prestasi Belajar, Yogyakarta: Pustaka Pelajar

Bafadal, Ibrahim, 2012, Supervisi Pendidikan Teori Dan Aplikasinya Dalam Membina Prifesionalitas Guru, Jakarta: Bumi Aksara

Bukhori, M., 2013, Teknik-teknik Evaluasi dalam Pendidikan, Bandung: Jammars

Hendayana, Sumar, et.al., 2017, Lesson Study, Suatu Strategi Untuk Meningkatkan Keprofesionalan Pendidik Pengalaman IMSTEP-JICA, Bandung: UPI Press

Imron, Ali, 2015, Pembinaan Guru Di Indonesia, Jakarta: Pustaka Jaya

Margono, S., 2016, Metodologi Penelitian Pendidikan, Jakarta: Rineka Cipta

Meini Sondag, "Lesson Study Untuk Meningkatkan Proses dan Hasil Pembelajaran", dalam unipajbr.files.wordpress.com/2011/02/100630-meini-lesson-study.doc

Sahertian, Piet A. dan Frans Mataheru, 2011, Prinsip Dan Teknik Supervisi Pendidikan, Surabaya:Usaha Nasional 
Sahertian, Piet A., 2010, Konsep Dasar Supervisi Pendidikan, Jakarta: PT. Rineka Cipta

Saylor, John Galen, t.th, Curriculum Planning for Better Teaching and Learning, Canada: Published Simultaneously

Subari, 2014, Supervisi Pendidikan Dalam Rangka Perbaikan Situasi Mengajar, Jakarta: Bumi Aksara

Sudjana, Nana, 2011, Dasar-dasar Proses Belajar Mengajar, Bandung: CV. Sinar Baru

------------, 2015, Penilaian Hasil Proses Belajar Mengajar, Bandung: Remaja Rosdakarya

Sugiyono, 2017, Metodelogi Penelitian Pendidikan Pendekatan Kuantitatif, Kualitatif dan $R \& D$ Bandung : Alfabeta

Sujiono, Anas, 2013, Pengantar Evaluasi Pendidikan, Jakarta: Pers

Susilo, Herawati, et.al., 2012, Lesson Study Berbasis Sekolah” Guru Konservatif Menuju Guru Inovatif”, Malang: Bayumedia Publishing

Sutopo, Hendiyat dan Wasty Sumanto, 2018, Kepemimpinan Dan Supervisi Pendidikan, Jakarta: PT. Bina Aksara

Thoha, M. Chabib, 2014, Teknik Evaluasi Pendidikan, Jakarta: PT. Raja Grafindo Persada

Widhiartha, Putu Ashintya, et.al., 2018, Lesson Study, Sebuah Upaya Peningkatan Mutu Pendidik Pendidikan Nonformal, Surabaya: Prima Printing

Winkel, W.S., 2013, Psikologi Pendidikan dan Evaluasi Belajar, Jakarta: Gramedia

http://ideguru.wordpress.com/2010/04/09/lesson-study-untuk-meningkatkan-proses- danhasil-pembelajaran/

http://www.freewebs.com/santyasa/pdf2/implementasi Lesson_Study.pdf 